\title{
A Discussion about Push Forward Informatization Construction of the Educational Administration Management in Universities An Example of Beijing Institute of Graphic Communication
}

\author{
Yongli Zhang \\ Department of Teaching Affairs, the Beijing Institute of Graphic Communication, Beijing, China
}

\begin{abstract}
Take the Beijing institute of graphic communication for example, analyzes the current educational administration management in universities information construction achievements, problems, and puts forward countermeasures and Suggestions on how to improve.

Index Terms - Universities, Educational administration, informatization

Refers to the educational administration informatization in university educational administration management work, make full use of computer technology, multimedia technology and network communication technology in working platform, the modern management of school educational administration work.
\end{abstract}

\section{The Significance of University Educational} Administration Management Information Construction

A. Can effectively solve the inefficient teaching affairs of the problems of enrollment expansion policy

Beijing institute of graphic communication, for example, after the enrollment expansion policy, school students scale existing more than 5000 people, a total of 26 undergraduate majors, much more than before. And the original educational management mode can not adapt to the new situations of change, with the low efficiency of management, in order to solve this problem, the educational administration informatization construction has become a must.

\section{B. To effectively cope with multi-campus school educational} administration management information not clear problem

Beijing institute of graphic communication now scattered in four campuses, and the distance between these campuses are far apart, so that the educational administration information cannot communicate effectively, brings to the educational administration work difficulty, must to construct the educational administration management information platform, in order to maintain the stability of teaching order and unity.
2. University educational administration management information construction has been achieved

A. Set up a comprehensive educational administration management information platform

Beijing institute of graphic communication, for example, after 10 years of development and construction, a wide range of educational administration management information platform has been set up, and developed dozens of educational administration management software and systems, include: student status management system; teaching plan management system; student test scores; teachers' workload calculation system; teaching project management system, etc, it covers much of the content of the educational administration work, make the management more standardized and orderly than before.

\section{B. For teachers and students more convenient and quick service}

For instance, students can through the online course selection system directly, choose a course your interested in; Teachers can also submit the student test scores by PC at any your convenient time and place, has made great teachers and students' study and life.

\section{Problems existing in the Informatization Construction}

\section{A. Lack of effective integration educational informationization platform}

Although have developed a variety of different functions of educational administration management software and systems, but these were developed at different times, by different people, therefore, the data standards and format are not identical, and can't be blended with each other easily and shared effectively. Brought great inconvenience to practical work. 


\section{B. Lack of effective supervision and management system}

This is mainly manifested in two aspects. First, there is no specialized agency which can supervise platform construction effectively. Including at the beginning of the system design, the design and development, the necessity of argument whether reasonable, no regulation; On completion of a certain system is achieved all scheduled functions, without checking; After the system put into operation the actual effect of the lack of supervision and inspection, thus to work for the educational administration information system of orderly conduct left hidden trouble.

Second, there is no clear and standard work flow and management system, so different levels of educational administration workers can't clear their own responsibilities and scope, and have a negative impact to the educational administration work.

\section{Lack of more service function be developed}

Furthermore, some system for user interface design are not very friendly and easy to use, for the different needs of users to provide more services fewer module design.

\section{Advice and Summary}

A. Should attach great importance to the unification of data interchange standard between different systems. Important is must be as large as possible within the scope of the formation of a unified data exchange standard.

B. Attaches great importance to the construction of management rules and regulations

First of all, should be in school set up a specialized management institutions, members should include the professional and technical personnel and workers of the educational administration and so on, actual teaching management software is responsible for each item or system to supervise and control the design and development. Including its development and the necessity to carry on the argument, inspection on its design function realization degree, etc., to reduce the disturbance of human factors for the work;

Second, to perfect the educational administration department internal work processes and management regulation, make each managers are fully aware of their responsibilities and content, to ensure that the responsibility to the people.

\subsection{Increase the design of the service function in educational management information platform, provide more humanized service for the audience}

First of all, through various channels to understand teaching management information platform of all types of users to use feeling and demands, and according to their hopes to improve as much as possible, to add more humanized design, meet the needs of teachers and students.

Second, you can try to add some service function plate in the system, at the same time of users' convenience and information query, data for their different needs to provide effective information support.

\section{References}

[1] Ye Aibing. Decision support systems in deepening the exploration and practice of educational informatization construction. Journal of sun yat-sen university (natural science edition), 2009, (3): 53.

[2] Huang Qiaosi. University educational administration information management problems and countermeasures. Journal of jiamusi institute of education, 2013, (4): 103.

[3] Deng Yigui. The significance of the information management system of educational administration and practice. Journal of southwest agricultural university (social science edition), 2007, (2): 157 